Letters to the Editor

\title{
COVID-19 Masquerading as Chikungunya Fever
}

\author{
Waqas Ullah, Andrew Tran, Sohaib Roomi, Rehan Saeed and Usman Sarwar
}

Abington Jefferson Health, Abington, USA

\author{
Article history \\ Received: 08-04-2020 \\ Revised: 04-05-2020 \\ Accepted: $12-05-2020$ \\ Corresponding Author: \\ Waqas Ullah \\ Abington Jefferson Health, \\ Abington, USA \\ Email: Waqasullah.dr@gmail.com
}

\begin{abstract}
The COVID-19 outbreak is an unprecedented global public health challenge. It has a myriad of clinical presentations including fever, cough, vomiting, and diarrhea. Here, we present a unique case of COVID19, with an atypical presentation of arthralgias and false-positive results for the chikungunya virus. By highlighting the importance of this rare association, we want physicians to be vigilant in the time of this pandemic and to have a high suspicion for this novel disease.
\end{abstract}

Keywords: COVID-19, CHIKV

\section{To the Editor}

On March 15, 2020, a 66-year-old Indian male with past medical history of diabetes mellitus and hyperlipidemia presented to the Emergency Department (ED) for evaluation of persistent febrile illness associated with diffuse body aches, arthralgias and chills for one week. He denied any shortness of breath, cough, diarrhea, chest tightness or sputum production. He had returned to the United States ten days prior after travelling to KolkataCalcutta, India. He stayed in India for 2 weeks and did not take any prophylactic medications or vaccination before or after his travel. While in India, he was traveling to different areas of the city for recreational purposes without using any protection against insect bites. He had a positive contact with a friend from London, who had cough and fever and later was diagnosed with the novel Coronavirus Disease (COVID-19).

On presentation, he was febrile $\left(101.2 \mathrm{~F}^{\circ}\right)$ and tachycardic with a heart rate of 130 beats per minute. His arterial oxygen saturation $\left(\mathrm{SaO}^{2}\right)$ was $97 \%$ on ambient room air. Physical examination demonstrated clear lung fields. Laboratory investigations were unremarkable except thrombocytopenia (platelet count of 80,000) and lymphopenia (Table 1). His influenza and respiratory syncytial virus tests were negative and chest X-ray was normal. His Electrocardiogram (EKG) showed sinus tachycardia with no abnormalities. Differential diagnosis at this point included parasitic infection (malaria, dengue), typhoid fever and COVID
19. Patient was empirically started on ceftriaxone $2 \mathrm{~g}$ daily, atovaquone and proguanil.

The following day, his malaria smear and dengue fever antibody $(1.05$, reference $<=1.65)$ tests were negative. Due to high-grade fever (at night-time only), rigors, chills and arthralgias, a rickettsial panel and Chikungunya Virus (CHIKV) titers were also sent. Over the next 2 days, he had persistent cyclical fevers despite being on acetaminophen, antibiotics and empiric antimalarial treatment. On day 5 the Rocky Mountain Spotted Fever (RMSF) and typhus antibodies were negative. The Enzyme-Linked Immunosorbent Assays (ELISAs) screening for CHIKV for IgG antibodies were remarkably elevated, $1: 160$ (ref <1:10). Antibiotics and antimalarial medications were discontinued and he was treated symptomatically for CHIKV fever. He remained on room air with no respiratory symptoms, his repeat CXR was also unremarkable.

On day 6, his real-time polymerase chain reaction (PCR) test for SARS-CoV-2 returned positive. Patient was immediately started on Hydroxychloroquine (HCQ) loading dose of 400mg twice a day for 1-day followed by $200 \mathrm{mg}$ twice a day for the next 4 days. His thrombocytopenia started improving and he had a remarkable symptomatic improvement with complete resolution of fever and arthralgias. He experienced no complications with the HCQ treatment. He had a Quantitative Reverse Transcription (qRT) PCR for CHIKV confirmation, which returned negative. He was discharged home in a stable condition with a plan to self-isolation. 
Table 1: Laboratory investigations of the patient during hospital stay

\begin{tabular}{|c|c|c|c|c|c|c|}
\hline Labs & Reference Range & $\begin{array}{l}\text { Hospital Day } 1 \\
\text { Symptom Day } 7\end{array}$ & $\begin{array}{l}\text { Hospital Day } 2 \\
\text { Symptom Day } 8\end{array}$ & $\begin{array}{l}\text { Hospital Day } 3 \\
\text { Symptom Day } 9\end{array}$ & $\begin{array}{l}\text { Hospital Day } 4 \\
\text { Symptom Day } 10\end{array}$ & $\begin{array}{l}\text { Hospital Day } 6 \\
\text { Symptom Day } 12\end{array}$ \\
\hline $\mathrm{WBC}, \mathrm{K} / \mathrm{UL}$ & {$[4.0-12.0]$} & 4.5 & 4 & 4.7 & 6.7 & 5.3 \\
\hline Hemoglobin, g/dL & [14.0-18.0] & 14 & 13.7 & 12.3 & 12 & 13.2 \\
\hline Platelets, K/UL & {$[140-400]$} & 80 & 87 & 72 & 82 & 196 \\
\hline Absolute Neutrophils, K/UL & {$[1.8-9.0]$} & 3.3 & 2.5 & 3.8 & 5.6 & 3.6 \\
\hline Abs Lymph, K/UL & {$[1.5-3.2]$} & 0.9 & 1.1 & 0.7 & 0.9 & 1.1 \\
\hline Abs Mon, K/UL & {$[0.0-0.9]$} & 0.3 & 0.4 & 0.3 & 0.3 & 0.5 \\
\hline Abs Baso, K/UL & {$[0.0-0.2]$} & 0 & 0 & 0 & 0 & 0 \\
\hline Abs Eosinophils, K/UL & {$[0.0-0.5]$} & 0 & 0 & 0 & 0 & 0 \\
\hline Lactic Acid & {$[0.5-1.9]$} & 1.1 & & & & \\
\hline Glucose (Random), mg/dL & {$[70-100]$} & 113 & 105 & 125 & 124 & 114 \\
\hline BUN, mg/dL & {$[0-23]$} & 10 & 9 & 7 & 6 & 7 \\
\hline Creatinine, $\mathrm{mg} / \mathrm{dL}$ & {$[0.00-1.25]$} & 0.87 & 0.77 & 0.77 & 0.71 & 0.74 \\
\hline Sodium, $\mathrm{mEq} / \mathrm{L}$ & {$[135-145]$} & 133 & 137 & 135 & 137 & 138 \\
\hline Potassium, $\mathrm{mEq} / \mathrm{L}$ & {$[3.5-5.1]$} & 3.9 & 4.2 & 3.8 & 3.9 & 4.1 \\
\hline Bicarbonate, $\mathrm{mEq} / \mathrm{L}$ & [20-31] & 24 & 20 & 21 & 22 & 24 \\
\hline AST, U/L & {$[5-34]$} & 19 & 19 & & & \\
\hline $\mathrm{ALT}, \mathrm{U} / \mathrm{L}$ & {$[0-55]$} & 17 & 17 & & & \\
\hline Alkaline Phosphatase, U/L & {$[40-150]$} & 67 & 65 & & & \\
\hline Total Bilirubin, mg/dL & {$[0.2-1.2]$} & 0.6 & 0.5 & & & \\
\hline Calcium, mg/dL & [9.4-10.2] & 9 & 8.4 & 8.3 & 8.5 & 9.2 \\
\hline Albumin, gm/dL & {$[3.4-4.8]$} & 3.8 & 3.7 & & & \\
\hline
\end{tabular}

The novel Coronavirus Disease 2019 (COVID-19) outbreak is an unprecedented global public health challenge. Since the end of December 2019, when the first cases of Severe Acute Respiratory Syndrome Coronavirus-2 (SARS-CoV-2) were detected in Wuhan, the disease has spread exponentially (Zhu et al., 2020; Guan et al., 2020; Chong et al., 2004). On January 30, 2020, the World Health Organization (WHO) declared COVID-19 a public health emergency of international concern (PHEIC), later officially upgrading it as a global pandemic. As of April 4, 2020, more than 1,140,000 confirmed cases from over 180 countries and more than 60,000 deaths have been documented worldwide. The projected United States (US) death toll is greater than 240,000 with an estimated total burden of more than 1 million COVID-19 cases.

SARS-CoV-2 belongs to the $\beta$-coronaviridae cluster, making it the 3rd known zoonotic disease linked to the coronavirus family (after SARS-CoV-1 in 2003 and the Middle East Respiratory Syndrome (MERS) in 2014) (Chowell et al., 2015). SARS-CoV2 was suggested to be a recombinant virus having similar genetic information as bat-related coronavirus and similar codon usage bias as snake-related coronaviruses (Ji et al., 2020). An outbreak of SARSCoV-2 starting from China has now spread globally due to a complete lack of immunity against this new strain, high infectivity of the virus and unchecked human to human transmission. In approximately $88 \%$ of COVID-19 cases, fever is the most common presentation, followed by cough $(68 \%)$ and arthralgias (14\%) (Guan et al., 2020).
CHIKV, on the other hand is an arthropod-borne alphavirus transmitted by mosquitoes (Aedes aegypti and Aedes albopictus). Chikungunya is an African word meaning "stooped walk" because of the incapacitating febrile polyarthralgias seen in $90 \%$ of the CHIKV cases (Weaver and Lecuit, 2015). Diagnosis can be made using serological testing, however, real-time qRT-PCR was found to be 10-times more accurate than ELISA. CHIKV does not require enhanced precautions and is managed supportively (Yap et al., 2010) (Table 2).

In the present case, epidemiologic exposure (travel to India), fever, arthralgias and positive ELISA test for CHIKV antibodies, pointed towards the diagnosis of CHIKV infection. While a positive contact history with a confirmed case suggested the possibility of COVID-19, atypical features such as lack of cough and hypoxia and normal CXR argued against this diagnosis. Cross reactivity of COVID-19 and CHIKV antibodies on ELISA test further complicated the diagnosis and management of this case.

Since both COVID-19 and CHIKV share a common clinical spectrum, confirmation of the later with the goldstandard PCR is critical, especially during the ongoing pandemic of COVID-19. As suggested by our case, that diagnosis of CHIKV with ELISA testing could be misleading in presence of active COVID-19. False positive CHIKV in the setting of COVID-19 can lead to early termination of enhanced precautions and failure to offer definitive management to the patients, both of which can have dismal consequences in terms of both the outcomes for the patient and for the health of the community. More studies are needed to identify the varied presentations and clinical features of COVID-19. 
Waqas Ullah et al. / American Journal of Infectious Diseases 2020, 16 (2): 73.76 DOI: 10.3844/ajidsp.2020.73.76

Table 2: Differences and similarities among a spectrum of identical diseases

\begin{tabular}{|c|c|c|c|c|c|c|c|}
\hline & COVID-19 & $\begin{array}{l}\text { Chikungunya } \\
\text { Fever }\end{array}$ & Dengue & Zika & Malaria & Flu & RMSF \\
\hline $\begin{array}{l}\text { Primary } \\
\text { Vector }\end{array}$ & $\begin{array}{l}\text { Respiratory } \\
\text { Droplets }\end{array}$ & Aedes mosquito & Aedes mosquito & $\begin{array}{l}\text { Aedes mosquito; } \\
\text { sexual transmission; } \\
\text { Intrauterine } \\
\text { transmission }\end{array}$ & $\begin{array}{l}\text { Anopheles } \\
\text { mosquito }\end{array}$ & $\begin{array}{l}\text { Respiratory } \\
\text { Droplets }\end{array}$ & Ticks, mites \\
\hline $\begin{array}{l}\text { Causative } \\
\text { Agent }\end{array}$ & $S A R S-C o V-2$ & $\begin{array}{l}\text { Chikungunya } \\
\text { Virus }\end{array}$ & Dengue viruses & Zika Virus & $\begin{array}{l}\text { Plasmodium } \\
\text { species }\end{array}$ & $\begin{array}{l}\text { Influenza } \\
\text { A/B Viruses }\end{array}$ & $\begin{array}{l}\text { Rickettsia } \\
\text { rickettsii }\end{array}$ \\
\hline Symptoms & $\begin{array}{l}\text { Arthralgias. fever, } \\
\text { malaise, } \\
\text { nonproductive } \\
\text { cough, GI } \\
\text { symptoms, ageusia, } \\
\text { anosmia, respiratory } \\
\text { failure, ARDS }\end{array}$ & $\begin{array}{l}\text { Severe arthralgias/ } \\
\text { arthritis followed } \\
\text { by high fever and } \\
\text { malaise (most } \\
\text { common), rash, } \\
\text { myalgias, GI } \\
\text { symptoms }\end{array}$ & $\begin{array}{l}\text { Fever, rash, } \\
\text { arthralgias, severe } \\
\text { myalgias, headache, } \\
\text { GI symptoms, } \\
\text { hemorrhage, dengue } \\
\text { shock syndrome }\end{array}$ & $\begin{array}{l}\text { Low grade fever, } \\
\text { rash, headache, } \\
\text { arthralgia, myalgia, } \\
\text { GI symptoms, } \\
\text { conjunctivitis, } \\
\text { asymptomatic }\end{array}$ & $\begin{array}{l}\text { Cyclical fever, } \\
\text { chills, malaise, } \\
\text { arthralgias, } \\
\text { myalgias, GI } \\
\text { symptoms, Shock/ } \\
\text { Bleeding/Cerebral } \\
\text { malaria if severe }\end{array}$ & $\begin{array}{l}\text { Fever, } \\
\text { headache, } \\
\text { myalgias, } \\
\text { malaise }\end{array}$ & $\begin{array}{l}\text { High fever and } \\
\text { malaise followed by } \\
\text { prominent macular } \\
\text { or petechial rash, } \\
\text { intense myalgias, } \\
\text { conjunctivitis, } \\
\text { EKG abnormalities/ } \\
\text { encephalitis (severe) }\end{array}$ \\
\hline Signs & $\begin{array}{l}\text { Characteristic } \\
\text { findings on Chest } \\
\text { CT }\end{array}$ & - & $\begin{array}{l}\text { Hemorrhagic } \\
\text { tendencies (e.g. } \\
\text { positive tourniquet } \\
\text { test, petechiae, } \\
\text { ecchymoses, purpura, } \\
\text { mucosal or GI } \\
\text { bleeding), ascities }\end{array}$ & - & $\begin{array}{l}\text { Palpable Spleen, } \\
\text { Jaundice (usually } \\
\text { mild) }\end{array}$ & - & $\begin{array}{l}\text { Noncardiogenic } \\
\text { pulmonary edema } \\
\text { (rare) }\end{array}$ \\
\hline Labs & $\begin{array}{l}\text { Lymphopenia, } \\
\text { thrombocytopenia }\end{array}$ & Lymphopenia & $\begin{array}{l}\text { Neutropenia, } \\
\text { Thrombocytopenia, } \\
\text { Elevated Hematocrit, } \\
\text { Liver failure if } \\
\text { severe }\end{array}$ & Thrombocytopenia & $\begin{array}{l}\text { Anemia, Thrombocyt- } \\
\text { openia, Elevated } \\
\text { Transaminases, } \\
\text { Mild coagulopathy, } \\
\text { DIC and ARDS(severe) }\end{array}$ & None & $\begin{array}{l}\text { Thrombocytopenia, } \\
\text { hyponatremia (late), } \\
\text { azotemia }\end{array}$ \\
\hline Imaging & $\begin{array}{l}\text { CXR-patchy or } \\
\text { diffuse airspace } \\
\text { opacities; CT Chest- } \\
\text { Peripheral ground } \\
\text { glass opacities, crazy } \\
\text { paving apperance, air } \\
\text { space consolidation, } \\
\text { bronchovascular } \\
\text { thickening, traction } \\
\text { bronchiectasis }\end{array}$ & None & $\begin{array}{l}\text { Pleural effusion } \\
\text { possible; } \\
\text { Microhemorrhages } \\
\text { for dengue } \\
\text { encephalitis }\end{array}$ & $\begin{array}{l}\text { Congenital zika } \\
\text { infection- structural } \\
\text { brain defects }\end{array}$ & $\begin{array}{l}\text { CTAP- } \\
\text { Hepatosplenomegaly }\end{array}$ & $\begin{array}{l}\text { CXR- Patchy, } \\
\text { BL infiltrates; } \\
\text { CT Chest- } \\
\text { Patchy bilateral } \\
\text { ground glass } \\
\text { opacities }\end{array}$ & None \\
\hline Diagnosis & RT-PCR; ELISA & $\begin{array}{l}\text { RT-PCR; ELISA, } \\
\text { IFA }\end{array}$ & RT-PCR; ELISA & RT-PCR; ELISA & Parasitemia & RT-PCR & $\begin{array}{l}\text { RT-PCR, IFA, } \\
\text { ELISA }\end{array}$ \\
\hline Management & $\begin{array}{l}\text { Supportive care; } \\
\text { some evidence of } \\
\text { hydroxychloroquine } \\
\text { and antivirals }\end{array}$ & $\begin{array}{l}\text { Supportive care; } \\
\text { DMARDs for } \\
\text { chronic arthralgias }\end{array}$ & $\begin{array}{l}\text { Supportive with goal } \\
\text { of maintaining } \\
\text { intravascular } \\
\text { volume }\end{array}$ & Supportive care & $\begin{array}{l}\text { Chloroquine, } \\
\text { Artemisinin-based } \\
\text { Combination } \\
\text { Therapies (ACT), } \\
\text { atovaquone-proguanil, } \\
\text { Quinine-based } \\
\text { regimens, Mefloquine }\end{array}$ & $\begin{array}{l}\text { Supportive care; } \\
\text { Neuraminidase } \\
\text { inhibitors, } \\
\text { selective } \\
\text { endonuclease } \\
\text { inhibitor baloxavir, } \\
\text { rarely adamantanes }\end{array}$ & $\begin{array}{l}\text { Supportive care; } \\
\text { Doxycycline } \\
\text { (preferred) }\end{array}$ \\
\hline Prognosis & $\begin{array}{l}\text { Age dependent; low } \\
\text { mortality }(\sim 0.2 \%) \text { in } \\
\text { patients }<40 \text { years } \\
\text { old, high mortality } \\
(>4 \%) \text { in patients } \\
>70 \text { years old }\end{array}$ & $\begin{array}{l}\text { Favorable, with } \\
\text { majority } \\
\text { recovering with } \\
\text { no symptoms }\end{array}$ & $\begin{array}{l}\text { Usually self limited, } \\
\text { rarely death from } \\
\text { dengue shock } \\
\text { syndrome }\end{array}$ & $\begin{array}{l}\text { Adults are usually } \\
\text { self limited; } \\
\text { congenital Zika } \\
\text { virus infection can } \\
\text { result in structural } \\
\text { brain defects }\end{array}$ & $\begin{array}{l}\text { Favorable if } \\
\text { uncomplicated, poor } \\
\text { if complicated }\end{array}$ & $\begin{array}{l}\text { Age dependent but } \\
\text { mostly favorable }\end{array}$ & $\begin{array}{l}\text { Favorable if treated, } \\
\text { fatal if untreated }\end{array}$ \\
\hline Prevention & $\begin{array}{l}\text { Handwashing; Strict } \\
\text { social isolation; } \\
\text { Quarantines; Vaccine } \\
\text { development } \\
\text { underway }\end{array}$ & $\begin{array}{l}\text { Mosquito } \\
\text { protection; } \\
\text { Vaccine } \\
\text { development } \\
\text { underway }\end{array}$ & $\begin{array}{l}\text { Mosquito } \\
\text { protection; } \\
\text { Vaccination }\end{array}$ & $\begin{array}{l}\text { Mosquito protection; } \\
\text { Vaccine } \\
\text { development } \\
\text { underway }\end{array}$ & $\begin{array}{l}\text { Mosquito protection; } \\
\text { Prophylactic } \\
\text { antibiotics }\end{array}$ & $\begin{array}{l}\text { Handwashing; } \\
\text { Quarantines; } \\
\text { Vaccination }\end{array}$ & $\begin{array}{l}\text { Avoid exposure to } \\
\text { wooded areas with } \\
\text { high grass; vigilant } \\
\text { monitoring for tick } \\
\text { bites }\end{array}$ \\
\hline
\end{tabular}

\section{Conclusion}

A positive ELISA test for arthropod-borne diseases should not preclude us from searching for COVID-19 during the times of SARS-CoV-2 pandemic. A Trioplex Real-time PCR, which tests for dengue, CHIKV and Zika viruses, is the gold-standard to differentiate these diseases from COVID-19. Large scale studies are required to validate our findings regarding the ELISA test.

\section{Author's Contributions}

All authors equally contributed in this work.

\section{Ethics}

This article is original and contains unpublished material. The corresponding author confirms that all of the other authors have read and approved the manuscript and no ethical issues involved. 


\section{References}

Chong, P.Y., P. Chui, A.E. Ling, T.J. Franks and D.Y. Tai et al., 2004. Analysis of deaths during the severe acute respiratory syndrome (SARS) epidemic in Singapore: challenges in determining a SARS diagnosis [J]. Arch. Pathol. Lab. Med., 128: 195$204 . \quad$ DOI: $10.1043 / 1543-$ 2165(2004)128<195:AODDTS > 2.0.CO;2

Chowell, G., F. Abdirizak, S. Lee, J. Lee and E. Jung et al., 2015. Transmission characteristics of MERS and SARS in the healthcare setting: A comparative study. BMC Med., 13: 210-210.

DOI: $10.1186 / \mathrm{s} 12916-015-0450-0$

Guan, W.J., Z.Y. Ni, Y. Hu, W.H. Liang and C.Q. Ou et al., 2020. Clinical characteristics of coronavirus disease 2019 in China. N. Engl. J. Med. DOI: 10.1101/2020.02.06.20020974

Ji, W., W. Wang, X. Zhao, J. Zai and X. Li, 2020. Homologous recombination within the spike glycoprotein of the newly identified coronavirus may boost cross-species transmission from snake to human. J. Med. Virol., 92: 433-440.

DOI: $10.1002 / j m v .25682$
Weaver, S.C. and M. Lecuit, 2015. Chikungunya virus and the global spread of a mosquito-borne disease. N. Engl. J. Med., 372: 1231-1239. DOI: $10.1056 /$ NEJMra1406035

Yap, G., K.Y. Pok, Y.L. Lai, H.C. Hapuarachchi and A. Chow et al., 2010. Evaluation of Chikungunya diagnostic assays: Differences in sensitivity of serology assays in two independent outbreaks. PLoS Neglected Tropical Dis., 4: e753-e753. DOI: 10.1371/journal.pntd.0000753

Zhu, N., D. Zhang, W. Wang, X. Li and B. Yang et al., 2020. A novel coronavirus from patients with pneumonia in China, 2019. N. Engl. J. Med., 382: 727-733. DOI: 10.1056/NEJMoa2001017 